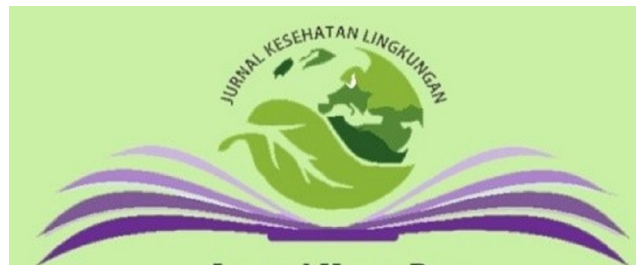

Journal Home Page:

https://e-journal.unair.ac.id/JKL

\section{Jurnal Kesehatan Lingkungan}

Vol. 14 No. 1

DOI: $10.20473 /$ jkl.vl4il.2022.1-10

ISSN: 1829 - 7285

E-ISSN: 2040 - 881X

\title{
A META-ANALYSIS OF RISK FACTORS OF LENGTH OF EXPOSURE, SMOKING HABITS, USE OF PERSONAL PROTECTION EQUIPMENT (PPE), AND EXPOSURE TO WELDING FUMES IN WELDING WORKERS WITH ABNORMAL PULMONARY FUNCTION (A PERSPECTIVE OF SUSTAINABLE PUBLIC HEALTH)
}

Nanda Inas Fauziyah ${ }^{1}$, R. Azizah ${ }^{1 *}$, Lailia Ayu Rachmawati ${ }^{1}$, Ahmad Zaharin Aris ${ }^{1,2}$, Arif Sumantri ${ }^{3}$, Siti N. A. Jauharoh ${ }^{4}$, Datu Buyung Agusdinata ${ }^{1,5}$

${ }^{1}$ Department of Environmental Health, Faculty of Public Health, Universitas Airlangga, Surabaya 60115, Indonesia

${ }^{2}$ Department of Environment, Faculty of Forestry and Environment, Universiti Putra Malaysia, 43400 UPM Serdang, Selangor, Malaysia

${ }^{3}$ Public Health Study Program, Faculty of Health

Science, Universitas Islam Negeri Syarif Hidayatullah

Jakarta, South Tangerang 15412, Indonesia

${ }^{4}$ Department of Clinical Pathology, Faculty of

Medicine, Universitas Islam Negeri Syarif Hidayatullah

Jakarta, South Tangerang 15412, Indonesia

${ }^{5}$ School of Sustainability, Arizona State University,

Tempe, AZ 85287, USA

\section{Corresponding Author:}

*) azizah@fkm.unair.ac.id

\section{Article Info}

$\begin{array}{ll}\text { Submitted } & : 9 \text { September } 2021 \\ \text { In reviewed } & : 1 \text { October } 2021 \\ \text { Accepted } & : 20 \text { December } 2021 \\ \text { Available Online } & : \text { 31 January } 2022\end{array}$

Keywords : Abnormal pulmonary function, Welding fumes, Smoking, Length of exposure, Personal protective equipment

Published by Fakultas Kesehatan Masyarakat Universitas Airlangga

\begin{abstract}
Introduction: About 11 million workers are welders worldwide, and more than 110 million workers are exposed to welding-related jobs. As many as $75.6 \%$ of welding workers in Pontianak, West Kalimantan, Indonesia, suffer from abnormal pulmonary function due to exposure to welding fumes. This study analyzed some risk factors and their sensitivity of abnormal pulmonary function in welding workers. Discussion: This study is a meta-analysis article. Data sources were obtained from articles published online on Google Scholar, Science Direct, Pubmed, and Springerfrom 2010 to 2020. A total of 15 articles were selected for meta-analysis using JASP version 0.9.2 software Results showed pooled prevalence ratio $(P R)$ values of long-exposure variables of $1.954(95 \% C I=0.31$ 1.03), smoking habits of 2.159 (95\% CI =0.33-1.22), USE of PPE $1.491(95 \%$ $C I=-0.50-1.30)$ and exposure to welding fumes $2.271(95 \% C I=0.52-1.12)$ in welding workers with abnormal pulmonary function. Conclusion: Exposure to welding fumes and smoking habits are the highest risk factors causing abnormal pulmonary function in welding workers. For workers, it is expected to reduce or stop smoking and always use PPE at work. For industry, control efforts are required by rotating work, conducting periodic worker medical examinations, providing exhaust with blowers in the workspace, and reinforcing the use of PPE at work.
\end{abstract}

\section{INTRODUCTION}

Welding is a critical process in industrial technology. Welding techniques mostly involve splicing of various metals. Welding is the process of splicing two metals, whether similar or not in types and added materials, by using heat energy to the point of metal recrystallization to dilute some of the parent metal (1-2). It is estimated that about 11 million workers worldwide are welders, and more than 110 million workers are exposed to welding fumes (3). Welding fumes are produced when a metal is heated to above its melting point, and it evaporates, and condenses into fumes. Metal particles are less than one $\mu \mathrm{m}$ that have solidified from the gaseous state (3-4). The toxicity of welding fumes depends on particle size, distribution, morphology, chemical composition, concentration, length of exposure, welder concision, number of operating welders, welding length, and thickness of the material spliced which determines the number of fumes produced (5-6). Moreover, judges from the risk score calculated based on hazard rate (HR) and exposure rate (ER), the most dangerous component of welding fumes is chromium (7). Chromium (VI) or hexavalent chromium is one of the toxic heavy metals widely used in various industries, including chrome coating (8). Chromium (VI) changes during the welding process are caused by the oxidation of Metals $\mathrm{Cr}$, and Chromium (III) by ozone or certain alkaline oxides 
in protected flux, which can form stable Chromium (VI) compounds that are suspected carcinogens (9).

Welding fumes can interfere with work comfort, visual impairment, general cause intoxication, and abnormal pulmonary function (10). Long-term exposure to welding fumes is associated with respiratory health problems, including asthma, bronchitis, changes in lung function, neurological disorders, cardiac arrhythmias, myocardial ischemia, atherosclerosis, and increased risk of cardiovascular disease e.g, hypertension (3). A study in Malaysia showed that welding workers suffered from coughing $(17.5 \%)$, phlegm $(21.4 \%)$, shortness of breath $(14.3 \%)$, wheezing $(14.3 \%)$, emphysema selfreported $(3.6 \%)$, emphysema diagnosed by doctors $(3.6 \%)$, asthma self-reported $(14.3 \%)$, and asthma diagnosed by doctors (10.7\%) (11). Besides, welding fumes have contributed $39.28 \%$ to the increase in lung damage in welding workers because of the chemical toxicity and long-term exposure (11). Regarding this, welding workers are at risk of exposure to higher welding fumes. Research conducted to fabrication workers at PT Pertamina (Persero) RU (Refinery Unit)-VI Balongan, Indramayu Regency found that the exposure to welding fumes was high with a severity value of 2 (moderate) and likelihood value of 4 (frequent) (12). Research in a shipbuilding industry factory in Iran showed that $57 \%$ of welding workers suffered from abnormal pulmonary function because of exposure to welding fumes (13). Research in Pontianak, West Kalimantan, Indonesia showed that $75.6 \%$ of welding workers had abnormal pulmonary function with a similar cause (14). Dose, length of exposure, and composition of welding fumes are able to likely affect abnormal pulmonary function (15).

Spirometers can be used for examining lung function. Spirometry examination can show dynamic volumes including PEFR (Peak Expiratory Flow Rate), MBC (Maximal Breathing Capacity) or MVV (Maximal Voluntary Ventilation), FEF $_{200-1200}$ (Forced Expiratory Flow $_{200-1200}$ ), FEF $_{25-75}$ (Forced Expiratory Flow $_{25 \%-75 \%}$ ), FEVT (Forced Expiratory Volume), and FVC (Forced Vital Capacity). A person who has an obstruction will show a decrease in standard vital capacity and the speed of expiratory flow in addition to decreased vital lung capacity because of more intense airflow and trapping air. FEV1/FVC is a widely used FEV value and is abnormal if reaching $<80 \%$. FEV1/FVC would be normal if the FVC value were deficient (16).

A study in welding workers showed that abnormal pulmonary function had a meaningful relationship with the length of exposure to welding fumes $(p=0.008$; $\mathrm{OR}=6.321 ; 95 \% \mathrm{Cl}=1.663-24.026)$, and workers who performed welding for $\geq 8$ hours/day had a smaller average lung capacity than for $<8$ hours/day (14). Exposure to welding for $\geq 8$ hours/day puts workers 6,321 times greater at risk of suffering from abnormal than for $<8$ hours/day. In addition to the length of exposure, research at the maintenance section of PT. $\mathrm{KAl}$ at Semarang Poncol Locomotive Dipo showed that $72.7 \%$ of welding workers who experienced abnormal lung function had smoking behavior, and smoking habits had a significant association with abnormal pulmonary function $(p=0.009)(17)$. Exposure to cigarette smoke and welding fumes has a synergistic effect on decreased pulmonary function among welding workers who smoke (18). Supporting the statement, research in Unizah, Qassim, Saudi Arabia, showed that workers who were simultaneously exposed to welding fumes and had smoking habits had worse pulmonary function (19).

Research in Punjab, India, showed that using personal protective equipment (PPE) is significantly associated with abnormal pulmonary function in welding workers (20). No use of PPE at work results in high risk of abnormal pulmonary function (21). Besides, research at the Moss shipyard, Perak, Malaysia showed that exposure to welding fumes is associated with abnormal pulmonary function. It found $\mathrm{FEV}_{1}$ and FVC in welding workers are lower than non-welding workers (22). Research in Lahore, Pakistan, showed that exposure to welding fumes at work is significantly associated with abnormal pulmonary function (23). Preventive measures are necessary to overcome health problems, especially abnormal pulmonary function, in welding workers.

The study aimed to analyze long-standing risk factors such as exposure, smoking habits, PPE use, and exposure to welding fumes and their sensitivity that might be associated with abnormal pulmonary function in welding workers.

\section{DISCUSSION}

This article is a meta-analysis article. Data were collected from journal articles and thesis that have been published online on Google Scholar, Science Direct, Pubmed, and Springer from 2010 to 2020. The search was done through Boolean logic/operator, namely OR and AND. Some keywords used were "Length of exposure" OR "Time exposure" AND "Smoke" OR "Smoking" AND "Personal protective equipment" AND "Welding fumes" AND "Pulmonary function disorder" OR "Lung function".

The inclusion criteria included; articles discussing the long-standing relationship between exposure to welding fumes, smoking habits, use of personal protective equipment (PPE), exposure to welding fumes, 
and abnormal pulmonary function; articles published from 2010 to 2020; articles conducted in welding workers; articles using a cross-sectional design; articles in Indonesian or English; full-text articles; articles analyzing the data. Fifteen articles were selected for meta-analysis (Figure 1).

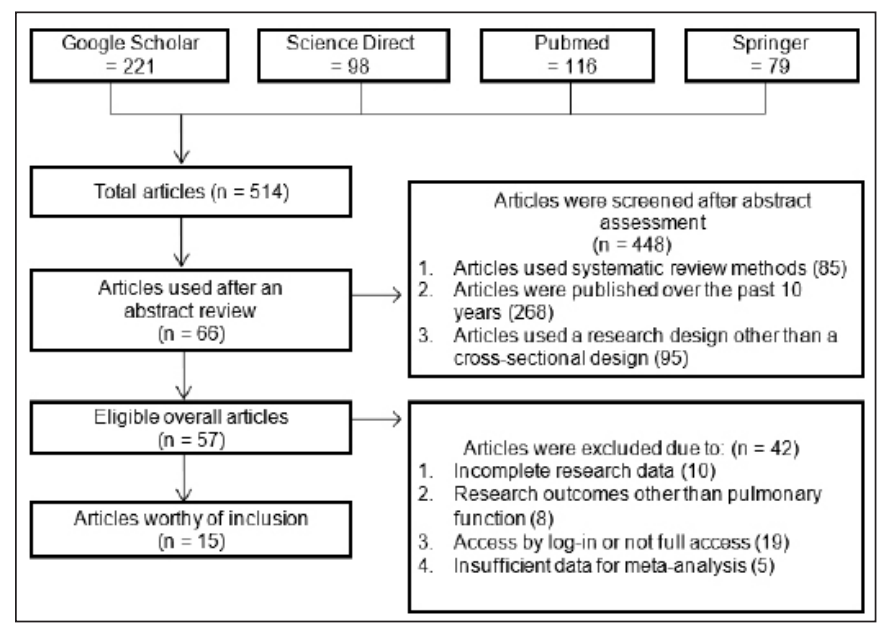

Figure 1. Selection of Articles for Meta-Analysis of Risk Factors Associated with Abnormal Pulmonary Function in Welding Workers

This study used a fixed effect analysis model or random effect analysis model. If the variation between variables was homogeneous ( $p>0.05$ ), the fixed effect model analysis model would be used. If the variation between variables was heterogeneous $(p<0.05)$, then the random effect model analysis model was used. The pooled odds ratio estimate was obtained after the use of Mantel-Haenszel analysis for the fixed-effect analysis and the DerSimonian-Laird analysis for the random effect analysis. A meta-analysis was performed using JASP version 0.9.2 software.

The meta-analysis calculated the prevalence ratio $(\mathrm{PR})$ value with a confidence interval $(\mathrm{Cl})$ of $95 \%$. If the $\mathrm{Cl}$ value of $95 \%$ passed $1(95 \% \mathrm{Cl}>1)$, then the variable was a risk factor. If the $\mathrm{Cl}$ value of $95 \%$ did not pass $1(95 \% \mathrm{Cl}<1)$, then the variable was not a risk factor but was included in protective factors. In this study, four variables e.g., length of exposure, smoking habits, use of PPE, and exposure to welding fumes were included as risk factors for abnormal pulmonary function in welding workers. The variables had the value of pooled $P R>1$, and $95 \% \mathrm{Cl}$ passed 1. Besides, a publication bias test was used using funnel plot in addition to sensitivity tests by comparing the analysis results.

\section{Meta-Analysis of Length of Exposure to Welding Fumes with Abnormal Pulmonary Function in Welding Workers}

In this study, there were five research articles that analyzed the long-standing relationship of exposure to abnormal pulmonary function in welding workers in Indonesia (14,24-27). The articles used a crosssectional design.

Based on Table 1, the heterogeneity tests showed a $p$-value greater than $0.05(p=0.354)$, meaning the variation between the studies was homogeneous. Since there was no variation between the variables, the fixedeffect analysis model was used. The selected articles displayed the relationship between length of exposure and abnormal pulmonary function in the forest plot (see Figure 2). It showed that the pooled prevalence ratio value was $1.954(95 \% \mathrm{Cl}=0.31-1.03)$. The publication bias test was not carried out on the length of exposure because there were only five studies out of minimum ten articles.

Long exposure is the length of time a worker can work and get exposed to the work environment in one day, calculated in hours. In this study, the length of exposure is classified into two categories: $>8$ hours per day and $<8$ hours per day. Figure 2 shows that the pooled prevalence ratio is $1.954(95 \% \mathrm{Cl}=0.31-1.03)$. Workers exposed to welding fumes for more than 8 hours/day had 1.954 times greater risk of experiencing abnormal pulmonary disorder than for less than 8 hours/day.

Based on the Government Regulations of Republic Indonesia No. 13 Year 2003 about Employment, working time is 8 hours per day or 40 hours per week (34). The standard time for a person working aims to maintain the health and safety of workers. If a person works beyond the standard, then she/he will likely experience health problems or diseases at work.

Research in Nigeria showed abnormal pulmonary function was significantly related to the length of work by welding workers (35). The longer the exposure to welding fumes, the greater the risk of abnormal pulmonary function $(23,36)$. Besides, prolonged exposure to welding fumes is associated with pulmonary function status. The long exposure to welding fumes leads to a significant decrease in pulmonary function parameters including $\mathrm{FVC}, \mathrm{FEV}_{1}, \mathrm{FEV}_{1} / \mathrm{FVC}$, and $\mathrm{MVV}$ in welding workers (37).

Research in Ankara, Turkey showed significant differences in $\mathrm{FEV}_{1} \%$ and $\mathrm{FEV}_{1} / \mathrm{FVC}$ ratio welding workers who worked more than 4 hours/day from the control group. $\mathrm{FEV}_{1} \%$ was predicted to be lowest with $80.5 \%$ occurring in welding workers exposed to welding smoke more than 4 hours a day, and the lowest $\mathrm{FEV}_{1} / \mathrm{FVC}$ ratio with $89.4 \%$ occurred to the group exposed for more than 4 hours/day, followed by exposure for less than 4 hours per day in $95.9 \%$ and $102.8 \%$ of the control group (38). Furthermore, the lowest PEF occurred to $80.6 \%$ of the group exposed for more than 4 hours/day, followed by exposure for less than 4 hours/day in $89.6 \%$ and $90.6 \%$ 
of the control group (38). Research in Semarang, Central Java found welding workers exposed to welding fumes for 10 hours/day with a working period of $\geq 5$ years were at risk of suffering from abnormal pulmonary function (17). Similar findings were found in welding workers who worked for 5-11 hours/day and had an average working period of 5 years in the Shuaiba industrial area, Kuwait. The research found an association between length of exposure and abnormal pulmonary function (39).

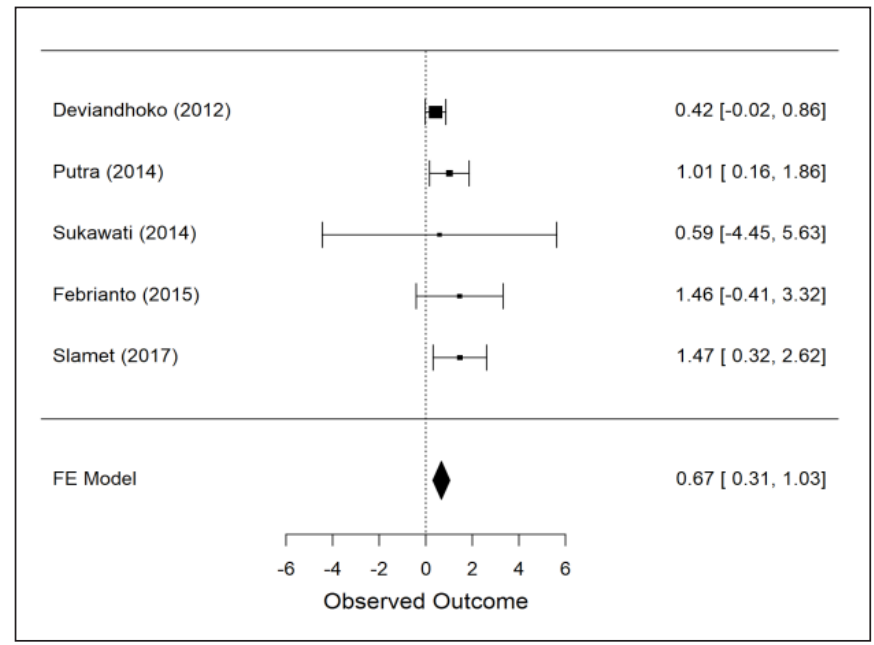

Pooled PR value $=e 0,67=1.954$

(a)

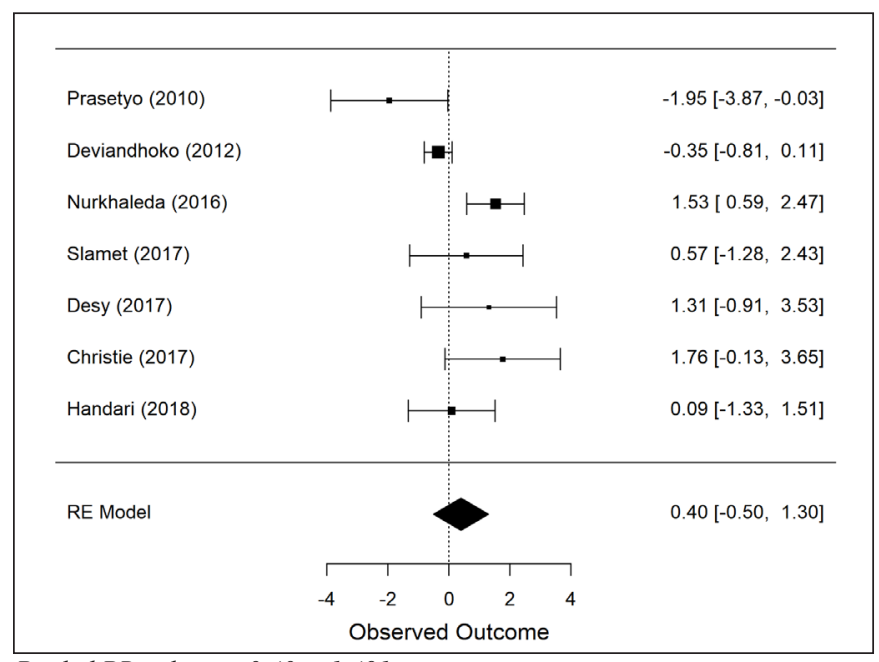

Pooled PR value $=e 0.40=1.491$

(c)
Therefore, efforts are warranted to minimize, prevent, and reduce the risk factors for abnormal pulmonary function in welding workers. For example, the companies have to apply strict laws and regulations at work, provide technical training on welding and occupational health and safety, as well as appropriate orientation sessions on workplace hazards. In addition to these efforts, the companies have to conduct regular medical check-ups in the workers.

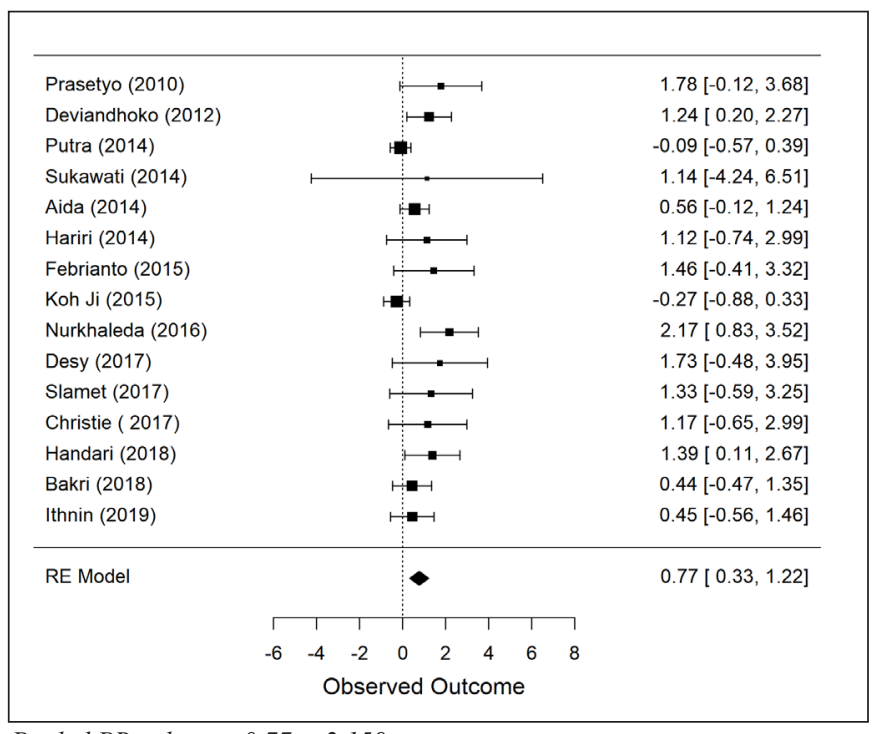

Pooled PR value $=e 0.77=2.159$

(b)

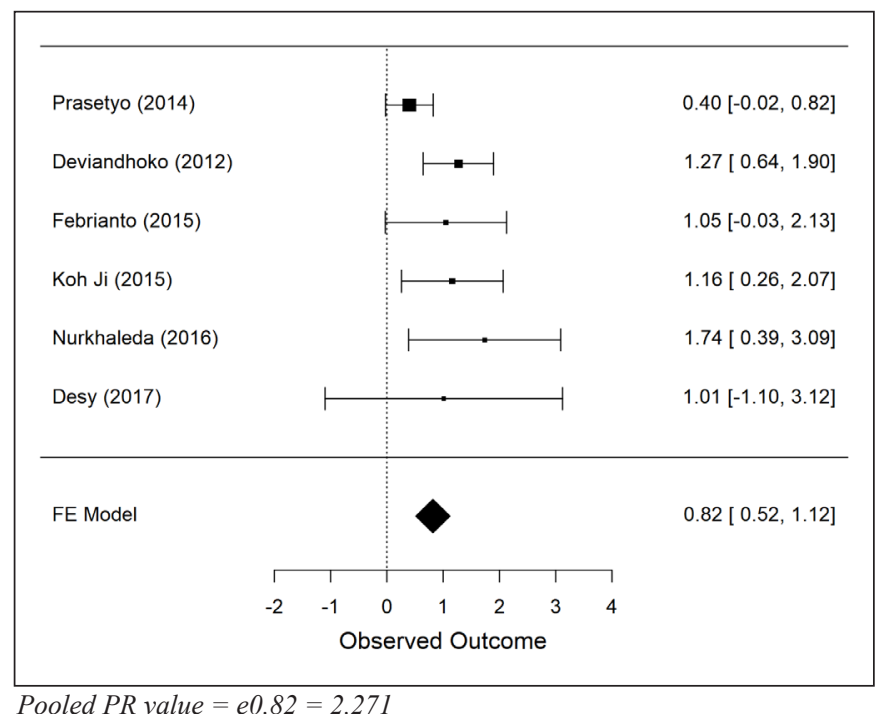

(d)

Description:

: Black diamond shows pooled PR
: Horizontal line indicates $95 \%$ CI

Figure 2. Forest Plot of Risk Factors for Abnormal Pulmonary Function in Welding Workers

(a)Forest plot of length of exposure; (b) Forest plot of smoking habits; (c) Forest plot of use of Personal Protection Equipment (PPE); (d) Forest plot of exposure to welding fumes. 
Meta-Analysis of Smoking Habits in Association with Abnormal Pulmonary Function in Welding Workers

Fifteen articles were analyzed for the relationship between smoking behavior and abnormal pulmonary function in welding workers $(11,14,17,21-22,24-33)$. Those articles used a cross-sectional design.

Table 1. Heterogeneity Test of Risk Factors in Welding Workers

\begin{tabular}{|c|c|c|c|c|}
\hline \multicolumn{2}{|c|}{ Meta-Analysis Using Heterogeneity Test } & \multirow{2}{*}{$\begin{array}{c}\mathbf{Q} \\
13.145\end{array}$} & \multirow{2}{*}{$\begin{array}{c}\mathbf{d f} \\
1\end{array}$} & \multirow{2}{*}{$\begin{array}{c}\mathbf{p} \\
<0.001\end{array}$} \\
\hline $\begin{array}{l}\text { Length of Exposure to } \\
\text { Welding Fumes in Association } \\
\text { with Abnormal Pulmonary } \\
\text { Function in Welding Workers }\end{array}$ & $\begin{array}{l}\text { Omnibus test of } \\
\text { model coefficients }\end{array}$ & & & \\
\hline $\begin{array}{l}\text { Analysis model: } \\
\text { Fixed effects model }\end{array}$ & $\begin{array}{l}\text { Test of residual } \\
\text { heterogeneity }\end{array}$ & 4.406 & 4 & 0.354 \\
\hline \multirow{2}{*}{$\begin{array}{l}\text { Smoking Habits in Association } \\
\text { with Abnormal Pulmonary } \\
\text { Function in Welding Workers } \\
\text { Analysis model: } \\
\text { Random effects model }\end{array}$} & $\begin{array}{l}\text { Omnibus test of } \\
\text { model coefficients }\end{array}$ & 11.84 & 1 & $<0.001$ \\
\hline & $\begin{array}{l}\text { Test of residual } \\
\text { heterogeneity }\end{array}$ & 27.26 & 14 & 0.018 \\
\hline \multirow{2}{*}{$\begin{array}{l}\text { Use of Personal Protection } \\
\text { Equipment (PPE) in } \\
\text { Association with Abnormal } \\
\text { Pulmonary Function in } \\
\text { Welding Workers } \\
\text { Analysis model: } \\
\text { Random effects model }\end{array}$} & $\begin{array}{l}\text { Omnibus test of } \\
\text { model coefficients }\end{array}$ & 0.750 & 1 & 0.387 \\
\hline & $\begin{array}{l}\text { Test of residual } \\
\text { heterogeneity }\end{array}$ & 21.283 & 6 & 0.002 \\
\hline \multirow{2}{*}{$\begin{array}{l}\text { Exposure to Welding Fumes } \\
\text { in Association with Abnormal } \\
\text { Pulmonary Function in } \\
\text { Welding Workers } \\
\text { Analysis model: } \\
\text { Fixed effects model }\end{array}$} & $\begin{array}{l}\text { Omnibus test of } \\
\text { model coefficients }\end{array}$ & 28.233 & 1 & $<0.001$ \\
\hline & $\begin{array}{l}\text { Test of residual } \\
\text { heterogeneity }\end{array}$ & 8.293 & 5 & 0.141 \\
\hline
\end{tabular}

Based on Table 1, the heterogeneity test indicated a $p$-value was smaller than $0.05(p=0.018)$, meaning the variation between the studies was heterogeneous; the analysis was done using the random effect model. The forest plot showed the relationship between smoking habit and abnormal pulmonary function with a pooled prevalence ratio of $2.159(95 \% \mathrm{Cl}=0.33-1.22)$.

Based on Figure 3, the funnel plot results showed publication bias because the model was symmetrical. The black circle was partly outside the triangle area, and the Egger's test was smaller than $0.05(p=<0.001)$.

Changes in respiratory tract function, structure, and lung tissue can be caused by smoking (32). Cigarettes have compounds that can settle in the lungs and thus harm them (17). In this study, the pooled prevalence ratio was $2.159(95 \% \mathrm{Cl}=0.33-1.22)$. It indicated welding workers who were smokers had 2.159 times greater to suffer from abnormal pulmonary function than those who did not smoke.
Smoking behavior is one of the factors that cause respiratory disorders (22). Research in Namibia showed that smoking behavior is associated with adverse effects on lung function (40). It is associated with a decrease in the spirometry index of lung function (41). Research in Semarang, Central Java discovered that, on average, welding workers who had smoking habits could consume 16 to 20 cigarettes/day. The lung capacity was related to smoking behavior among welding workers (31). The more the use of cigarettes, the higher the risk of abnormal pulmonary function (42). Research in Poland stated that welding workers who had smoking behavior had a lower $\mathrm{FEV}_{1} / \mathrm{FVC}$ ratio than those who were non-smokers. Thus, welding workers who have smoking habits are at risk of suffering from abnormal lung function (43).

Moreover, studies analyzing exposure to secondhand smoke and welding fumes simultaneously could decrease multiple spirometry indices, including $\% \mathrm{FEV}_{1}, \% \mathrm{FEV}_{1} / \mathrm{FVC}, \mathrm{FEV}_{1} / \mathrm{FVC}, \% \mathrm{PEF}, \% \mathrm{FEF}_{25-75}$, and $\mathrm{FEF}_{25-75}(44)$. This suggests a synergistic effect between exposure to cigarette smoke and welding fumes could aggravate lung conditions. Efforts are required to minimize and reduce the risk of abnormal lung function in smoking workers through health education on the harms of smoke. In addition, companies/agencies have to carry out regular medical check-ups to monitor the health status of their workers.

Meta-Analysis of Use of Personal Protection Equipment (PPE) in Association with Abnormal Pulmonary Function in Welding Workers

Seven research articles discussed the relationship between use of personal protection equipment and abnormal pulmonary function $(14,17,21,24,31-33)$. The articles used a cross-sectional design.

The heterogeneity test showed a p-value was smaller than $0.05(p=0.002)$, meaning the variation between the studies was heterogeneous. Thus, this analysis was done using a random effect model. Figure 2 showed the forest plot on seven research articles that discussed the relationship between use of PPE and abnormal pulmonary function in welding workers. It showed that the pooled prevalence ratio was 1.491 $(95 \% \mathrm{Cl}=-0.50-1.30)$. The publication bias test was not carried out because the meta-analysis included less than ten studies. 


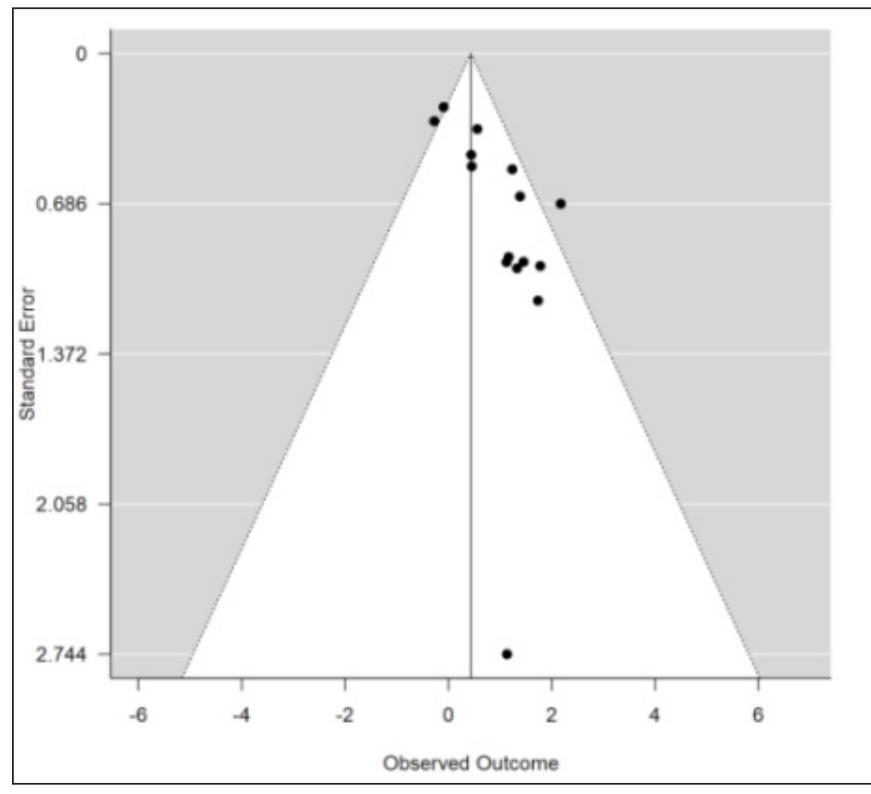

Figure 3. Funnel Plot of Smoking Habits Associated with Abnormal Pulmonary Function in Welding Workers

The use of personal protective equipment (PPE) plays a crucial role in the occupational safety and health. It minimizes exposure to various hazards, thereby creating a healthier workplace (45). In addition, it has a significant relationship with occupational diseases in welding workers. For example, workers who did not wear PPE had 1.5 times greater risk of suffering occupational diseases than workers who wore PPE (46). Figure 2c shows with the pooled prevalence ratio of 1.491 (95\% $\mathrm{Cl}-0.50-1.30$ ), welding workers who did not use PPE e.g., masks had 1.491 times greater risk of suffering from abnormal pulmonary function than workers who wore PPE.

Research in Semarang, Central Java, showed a link between the use of masks and abnormal pulmonary function $(p=0.001)$ (31). Masks can reduce inhalation of welding fumes (35). Research in Semarang, Central Java showed similar findings (31). Besides, research in Terengganu, Malaysia, found that the frequency of mask use had a positive and significant association with FVC values $(p=0.011)(47)$.

Research in Delta, Nigeria, showed a significant association $\left(X^{2}=233.893 a ; D F=3 ; P<0.05\right)$ between education level and use of PPE in welding workers (48). Research in Deli Serdang, North Sumatra, found that the use of PPE is significantly related to knowledge, attitudes, and actions performed by welding workers (49). The research pointed out that most of the welding workers were less knowledgeable due to insufficient information about the importance of using PPE at work. In addition, most welding workers had a negative attitude of using PPE since they did not understand the importance of using PPE for work safety.
Similarly, research in Binjai, North Sumatra, showed knowledge and especially attitude of workers affected the use of PPE (50). A study in Medan, North Sumatra, also found that workers who disregarded the use of PPE mostly did not know the benefits of using PPE. For example, they assume that face shields can be replaced by ordinary dark glasses. Reluctance to use PPE could reduce work productivity and cause rejection to using PPE (51).

Speaking about the support from the management, welding workshop owners did not impose much support on the use of PPE, and thus welding workers tend to take it for granted (51). This follows the research in Semarang, Central Java, showing that the length of work, work regulations, peer support, and leader support affected workers to use PPE (52). Proper and strict regulations regarding the use of PPE and respirators in welding industries successfully control exposure to heavy metal fumes (53).

Therefore, regulations must be placed to reinforce the use of PPE, such as face shields, welding helmets, glasses, gloves, welding masks, and respirators at work. Companies should educate workers on the importance of occupational safety and health, as well as push them to use PPE.

\section{Meta-Analysis of Exposure to Welding Fumes in Association with Abnormal Pulmonary Function in Welding Workers}

Six research articles collected discussed about the relationship between exposure to welding fumes and abnormal pulmonary function in Indonesia $(24-25,27,30$ 32). All of them utilized a cross-sectional design.

Table 1 shows the variation between the studies was homogenous with a p-value of 0.141 . This analysis was performed using the fixed effect model. The forest plo showed that the pooled prevalence ratio was 2.271 $(95 \% \mathrm{Cl} 0.52-1.12)$. The publication bias test was not carried out to this variable for exposure since less than ten studies were included.

Tabel 2. Comparation of Sensitivity Tests on Pooled Prevalence Ratio Using Fixed Model and Random Model

\begin{tabular}{|c|c|c|c|c|c|c|}
\hline \multirow{2}{*}{$\begin{array}{l}\text { Research } \\
\text { Variables }\end{array}$} & \multirow{2}{*}{ n } & \multirow{2}{*}{$\begin{array}{l}\text { Heterogenity } \\
\text { (p-value) }\end{array}$} & \multicolumn{2}{|c|}{$\begin{array}{c}\text { Fixed Effect } \\
\text { Models }\end{array}$} & \multicolumn{2}{|c|}{$\begin{array}{c}\text { Random } \\
\text { Effect Model }\end{array}$} \\
\hline & & & $\mathbf{P R}$ & $\begin{array}{c}95 \% \\
\text { CI }\end{array}$ & PR & $95 \%$ CI \\
\hline $\begin{array}{l}\text { Length of } \\
\text { Exposure }\end{array}$ & 5 & 0.354 & 1.954 & $0.31-1.03$ & 2.339 & $0.28-1.41$ \\
\hline Smoking Habits & 15 & 0.018 & 1.537 & $0.18-0.69$ & 2.159 & $0.33-1.22$ \\
\hline $\begin{array}{l}\text { Use of Personal } \\
\text { Protection } \\
\text { Equipment } \\
\text { (PPE) }\end{array}$ & 7 & 0.002 & 1.073 & $-0.30-0.43$ & 1.491 & $-0.50-1.30$ \\
\hline $\begin{array}{l}\text { Exposure to } \\
\text { Welding Fumes }\end{array}$ & 6 & 0.141 & 2.271 & $0.52-1.12$ & 2.364 & $0.51-1.45$ \\
\hline
\end{tabular}


Test Sensitivity of Length of Exposure, Smoking Habits, Use of Personal Protection Equipment (PPE), and Exposure to Welding Fumes in Association with Abnormal Pulmonary Function in Welding Workers

Identifying heterogenesis, interpreting the effects of research quality, and proving relatively stable meta-analysis results can be done using sensitivity tests. The sensitivity test compared the pooled Prevalence Ratio (PR) fixed and random models. The comparison between the random model analysis model and the fixed model results can be seen in table 2 .

Fumes are polluting pollutant materials or particulates produced from the welding process (54). The threshold limit value-time weighted average (TLV-TWA) value for exposure to fumes is $5 \mathrm{mg} / \mathrm{m}^{3}$ (3). Research conducted at PT. PAL Indonesia, the largest shipyard company in Indonesia, showed workers with abnormal pulmonary function worked in an environment with high exposure to welding fumes (32). In the current work study, with the pooled prevalence ratio of 2.271 (95\% $\mathrm{Cl}=0.52-1.12)$. The workers who got exposed to fumes above the threshold had 2.271 times greater chances of suffering from abnormal pulmonary function compared to those under threshold value.

Exposure to welding fumes harms pulmonary function (44). Research in Stockholm, Sweden, showed that exposure to welding fumes was associated with abnormal pulmonary function (55). Research in Punjab, India showed a significant difference in the mean of the lung function parameters between welders and nonwelders $(p<0.05)$. The average of the FVC, FEV ${ }_{1}$, and $\mathrm{FEV}_{1} / \mathrm{FVC}(3.37 \pm .175,2.59 \pm 0.16)$ was significantly lower in welding workers than non-welding workers (3.70 $\pm 0.15,3.05 \pm 0.25$ and $82.49 \pm 7.62)(20)$.

Research in a steel industry company in Ahvaz, Iran, discovered that welding workers experienced a significant decrease in lung function for all parameters ( $F V C, \mathrm{FEV}_{1}, \mathrm{FEF}_{25-75 \%}$, and $\mathrm{FEV}_{1} / \mathrm{FVC}$ ) (56). In addition, research in Monza showed that based on the spirometry lung function tests, abnormal pulmonary function was correlated inversely with years of exposure to welding fumes $\left(F E V_{1}: R^{2}=0.303 ; p=0.012 ; F V C: R 2=0.27\right.$; $p<0.02)$. This indicates that the longer the exposure to welding fumes, the lower the FEV 1 and FVC (57). Research in China showed that FVC, FEV1, and PEF values of welding workers after work were significantly lower than before work $(t=19.52,48.13,62.03 ; p<0.05)$. Every $1 \mathrm{mg} / \mathrm{m}^{3}$ increase in welding fumes in the workplace, FVC decreases by $1.02 \%$, and FEV ${ }_{1}$ decreases $1.56 \%$ compared to pre-employment values (58).
Controlling welding fumes in the workplace is important to avoid health problems. In addition, automotive part welding plant workers had lower $\mathrm{FEV}_{1}, \mathrm{FEV}_{1} / \mathrm{FVC}$, and PEF than non-welding part workers (44). This is in line with research in Nigeria where abnormal pulmonary function parameters significantly reduced all spirometry indices (including $\mathrm{FEV}_{1}, \mathrm{FVC}$, and $\mathrm{FEV}_{1} / \mathrm{FVC}$ ) in welding workers (35). PEFR and maximum flow rates at $50 \%$ and $25 \%$ of FVC were significantly lower among welding workers than non-welding workers in a Shuaiba industrial area, Kuwait (39).

To reduce risk and minimize the inhalation of welding fumes, companies have to use exhaust that can control the air circulation. The welding fumes taken off could be more quickly diluted by fresh air. Moreover, welding workers can wear welding masks (respiratory) to protect themselves from inhaling welding fumes.

\section{Limitations of Research}

This meta-analysis study has limitations. First, some research articles cannot be analyzed because the available data are inadequate for analysis. Second, some research articles do not present complete statistical data. Third, some articles used designs other than a cross-sectional design. The number of articles obtained is too small. Further studies need to collect more research articles to provide stronger evidence along with measurement methods used for each variable.

\section{ACKNOWLEDGEMENTS}

The authors would thank to all staff at Graduate Department of Environmental Health, Universitas Airlangga for their support.

\section{CONCLUSION}

From fifteen articles analyzed, risk of suffering from abnormal pulmonary function is 2.271 times greater for exposure to welding fumes, 2.159 for smoking habit, 1.954 for length of exposure to welding fumes, and 1.491 for use of PPE. The most dominant factor causing abnormal pulmonary function is exposure to welding fumes.

Companies need to control the risk of pulmonary function disorder by applying strict laws and regulations at work, provide PPE kit and technical training on the occupational health and safety, and hold proper orientation sessions on occupational hazards, as well as periodical medical examinations on workers. Workplace must have installation of exhaust that drain polluted air out. 


\section{REFERENCES}

1. Maulana Y. Analisis Kekuatan Tarik Baja ST37 Pasca Pengelasan dengan Variasi Media Pendingin Menggunakan SMAW. J Tek Mesin UNISKA. 2016;2(1):1-8. https://ojs.uniska-bjm.ac.id/index. php/JZR/article/view/545/472

2. Wahyudi R, Nurdin N, Saifuddin S. Analisa Pengaruh Jenis Elektroda pada Pengelasan SMAW Penyambungan Baja Karbon Rendah dengan Baja Karbon Sedang terhadap Tensile Strenght. J Weld Technol. 2019;1(2):43-47. http://e-jurnal.pnl.ac.id/ Welding_Technology/article/view/1645/1420

3. International Agency Research on Cancer. IARC Monographs on the Evaluation of Carcinogenic Risks to Humans. Lyon: International Agency Research on Cancer; 2018. 1-320 p. https://publications. iarc.fr/Book-And-Report-Series/larc-MonographsOn-The-Identification-Of-Carcinogenic-HazardsTo-Humans/Welding-Molybdenum-Trioxide-AndIndium-Tin-Oxide-2018

4. Suhardi B, Citrawati A, Astuti RD. Ergonomi Partisipatori Implementasi Bidang Kesehatan dan Keselamatan Kerja. Yogyakarta: Deepublish; 2021. https://books.google.co.id/ books?id=G9oWEAAAQBAJ

5. Basuki M, Santosa PI, Alfiah T. Penilaian Risiko Lingkungan (Environmental Risk Assessment) pada Pekerjaan Reparasi Kapal di Perusahaan Galangan Kapal. Prosiding Seminar Nasional Aplikasi Sains dan Teknologi. 2016;1:567-570. https://ejournal. akprind.ac.id/index.php/prosidingsnast/article/ view/1624

6. Erdem JS, Arnoldussen YJ, Tajik S, Ellingsen DG, Zienolddiny S. Effects of Mild Steel Welding Fume Particles on Pulmonary Epithelial Inflammation and Endothelial Activation. Toxicol Ind Health. 2020;36(12):995-1001. https://doi. org/10.1177\%2F0748233720962685

7. Mehrifar Y, Zeverdegani SK, Rismanchian M. Chemical Pollutants in the Respiratory Zone of Welders: Determination of Concentrations and Hazard Analysis. Work. 2020;67(3):591-598. https://doi.org/10.3233/wor-203272

8. Teklay A. Physiological Effect of Chromium Exposure: A Review. Int J Food Sci Nutr Diet. 2016;S7(1):1-11. http://dx.doi.org/10.19070/23263350-SI07001

9. Sivapirakasam SP, Mohan S, Kumar MCS, Paul TA, Surianarayanan M. Control of Exposure to Hexavalent Chromium Concentration in Shielded Metal Arc Welding Fumes by Nano-Coating of Electrodes. Int $J$ Occup Environ Health. 2017;23(2):128-142. https://doi.org/10.1080/1077 3525.2018.1436014

10. Qolik A, Yoto Y, Basuki B, Sunomo S, Wahono W. Bahaya Asap dan Radiasi Sinar Las Terhadap Pekerja Las di Sektor Informal. J Tek Mesin dan Pembelajaran. 2018;1(1):1-4. http://dx.doi. org/10.17977/um054v1i1p1-4

11. Bakri SFZ, Hariri A, Ismail M, Abdullah S, Kassim NI. Evaluation of Respiratory Symptoms, Spirometric Lung Patterns, and Metal Fume Concentrations among Welders in Indoor Air-Conditioned building at Malaysia. Int J Integr Eng. 2018;10(5):109-121. https://publisher.uthm.edu.my/ojs/index.php/ijie/ article/view/3038

12. Ambarani AY, Tualeka AR. Hazard Identification and Risk Assessment (HIRA) pada Proses Fabrikasi Plate Tanki 42-T-501a PT Pertamina (Persero) RU VI Balongan. Indones J Occup Saf Heal. 2017;5(2):192-203. http://dx.doi.org/10.20473/ ijosh.v5i2.2016.192-203

13. Mehrifar $Y$, Zamanian Z, Pirami H. Respiratory Exposure to Toxic Gases and Metal Fumes Produced by Welding Processes and Pulmonary Function Tests. Int J Occup Environ Med. 2019;10(1):40-49. https://dx.doi.org/10.15171\%2Fijoem.2019.1540

14. Slamet, Kamilla L. Faktor-Faktor yang Berhubungan dengan Gangguan Fungsi Paru pada Pekerja Pengelasan di Kota Pontianak. J Lab Khatulistiwa. 2017;1(1):89-83. https://doi.org/10.30602/jlk. v1i1.100

15. Riccelli MG, Goldoni M, Poli D, Mozzoni P, Cavallo D, Corradi M. Welding Fumes, a Risk Factor for Lung Diseases. Int J Environ Res Public Health. 2020;17(7):2552. https://doi.org/10.3390/ ijerph17072552

16. Bakhtiar A, Tantri RIE. Faal Paru Dinamis. $J$ Respirasi. 2017;3(3):89-96. http://dx.doi. org/10.20473/jr.v3-I.3.2017.89-96

17. Handari MC, Sugiharto, Pawenang ET. Karakteristik Pekerja dengan Kejadian Gangguan Fungsi Paru pada Pekerja Dipo Lokomotif. Higeia J Public Heal Res Dev. 2018;1(3):84-94. https://journal.unnes. ac.id/sju/index.php/higeia/article/view/17542

18. Roach LL. The Relationship of Welding Fume Exposure, Smoking, and Pulmonary Function in Welders. Work Heal Saf. 2018;66(1):3440. https://journals.sagepub.com/doi/ abs/10.1177/2165079917723927

19. Rahmani A, Golbabaei F, Dehghan SF, Mazlomi A, Akbarzadeh A. Assessment of the Effect of Welding Fumes on Welders' Cognitive Failure and Healthrelated Quality of Life. Int J Occup Saf Ergon. 2016;22(3):426-432. https://doi.org/10.1080/1080 3548.2016.1164499

20. Dev M, Bhardwaj A. Respiratory Symptoms and Spirometric Abnormalities Among Welders in the Welding Workplace of the Indian Unorganized Sector. Work. 2021;69(3):885-894. https://doi. org/10.3233/wor-213521

21. Pasaribu MAC. Hubungan Paparan Debu Las dengan Gangguan Faal Paru pada Pekerja Pengelasan di Kelurahan Mesjid Kecamatan Medan Kota. Skripsi. Medan: Universitas Sumatera Utara; 2017. http://repositori.usu.ac.id/

22. Ithnin A, Zubir A, Awang N, Sulaiman NNM. Respiratory Health Status of Workers that Exposed to Welding Fumes at Lumut Shipyard. Pakistan J Biol Sci. 2019;22(3):143-147. https://doi.org/10.3923/ pjbs.2019.143.147

23. Ghani N, Tariq F, Hassan S. Respiratory and Physical Ailments Correlated with Occupational 
Exposure among Welders in Pakistan. J Pak Med Assoc. 2017;67(12):1910-1913. https://pubmed. ncbi.nlm.nih.gov/29256540/

24. Deviandhoko, Wahyuningsih NE, Nurjazuli. FaktorFaktor yang Berhubungan dengan Gangguan Fungsi Paru pada Pekerja Pengelasan di Kota Pontianak. J Lab Khatulistiwa. 2012;11(2):123-129. https://doi.org/10.14710/jkli.11.2.123\%20-\%20129

25. Putra ND. Faktor-Faktor yang Berhubungan dengan Kapasitas Vital Paru pada Pekerja Bengkel Las di Kelurahan Cirendeu. Skripsi. Jakarta: Universitas Islam Negeri Syarif Hidayatullah; 2014. https:// repository.uinjkt.ac.id/

26. Sukawati E, Setiani O, Nurjazuli. A Study on Pulmonary Function Disorders among Welders at Sub District of Mertoyudan in the District of Magelang. $J$ Kesehat Lingkung Indones. 2014;13(2):45-50. https://doi.org/10.14710/jkli.13.2.45\%20-\%2050

27. Febrianto AA, Sujoso ADP, Hartanti RI. Hubungan antara Karakteristik Individu, Paparan Debu Asap Las (Welding Fume) dan Gas Karbon Monoksida (CO) dengan Gangguan Faal Paru pada Pekerja Bengkel Las (Studi di Kelurahan Ngagel Kecamatan Wonokromo Surabaya). Pustaka Kesehat. 2015;3(3):515-521. https://jurnal.unej.ac.id/index. php/JPK/article/view/4007

28. Aziz NA, Jalaludin J. Exposure to $\mathrm{PM}_{10}$ and Lung Function among Welders of Metal Working Factory in Selangor. Heal Environ J. 2014;5(1):113-125. https://doi.org/10.7763/jocet.2014.v2.102

29. Hariri A, Paiman NA, Leman AM, Yusof MZM. Pulmonary Function Status among Welders in Malaysian's Automotive Industries. J Clean Energy Technol. 2014;2(2):108-111. http://www.jocet.org/ papers/102-E008.pdf

30. Koh DH, Kim JI, Kim KH, Yoo SW. Welding Fume Exposure and Chronic Obstructive Pulmonary Disease in Welders. Occup Med (Chic III). 2015;65(1):72-77. https://pubmed.ncbi.nlm.nih. gov/25324483/

31. Nurkhaleda B, Jayanti S, Suroto. Faktor-Faktor yang Berhubungan dengan Kapasitas Fungsi Paru pada Pekerja Pengelasan di PT.X Kota Semarang Tahun 2016. J Kesehat Masy. 2016;4(3):313-322. https://ejournal3.undip.ac.id/index.php/jkm/article/ view/12908

32. Desy R, Sulistyorini L. The Analysis of Exposure Welding Fumes with Impaired Lung Faal Workers Welding PT. PAL Indonesia (Persero). J Kesehat Lingkung. 2017;9(2):154-162. http://dx.doi. org/10.20473/jkl.v9i2.2017.154-162

33. Prasetyo DR. Faktor-Faktor yang Berhubungan dengan Kapasitas Vital Paru Pada Pekerja Bengkel Las di Pisangan Ciputat Tahun 2010. Skripsi. Jakarta: Universitas Islam Negeri Syarif Hidayatullah Jakarta; 2010. 1-82 p. http://repository.uinjkt.ac.id/ dspace/handle/123456789/1021

34. President of Republic Indonesia. Government Regulations of Republic Indonesia No. 13 Year 2003 about Employment. Jakarta: Ministry of the State Secretariat; 2019.
35. Fasanmi KT. Respiratory Symptoms, Ventilatory Function and Health-Related Quality of Life of ArcWelders in Ile-lfe, a South Western City in Nigeria. Ann Pulm Res Med. 2020;1(1):1001. http://www. remedypublications.com/annals-of-pulmonaryrespiratory-medicine-abstract.php?aid $=5963$

36. Asrori A, Nurhayati N, Mutholib A, Ellinasari TF. Gambaran Kadar Asam Urat pada Pekerja Bengkel Las di Kecamatan Sukarami Palembang Tahun 2019. J Anal Kesehat. 2020;8(2):63-71. https:// ejurnal.poltekkes-tik.ac.id/index.php/JANALISKES/ article/download/1865/1079

37. Gawre VV, Chaudhari SP, Doiphode R, Gore C V, Khedkar SK. Preliminary Study of Spirometric Evaluation of Lung Functions in Arc Welding Workers. IJCAP. 2017;4(4):508-511. https://www. ijcap.org/article-details/5173

38. Cetintepe SP, Iritas SB, Gunduzoz M, Alaguney $\mathrm{ME}$, Wilson D, Bal C, et al. Relation Between Lung Dysfunction and Blood Cadmium and Lead Levels Among Welders. Expo Heal. 2019;11(1):13-19. https://link.springer.com/article/10.1007/s12403017-0262-x

39. Alateeq AEO, Daoud BH, El-Gamal FM, Foda NMT, Mehana SM. Respiratory Disorders, Pulmonary Functions and Radiological Abnormalities among Workers Exposed to Welding Fumes. Egypt J Occup Med. 2021;45(3):217-232. https://dx.doi. org/10.21608/ejom.2021.193278

40. Hamatui N, Naidoo RN, Kgabi N. Respiratory Health Effects of Occupational Exposure to Charcoal Dust in Namibia. Int $J$ Occup Environ Health. 2016;22(3):240-248. http://dx.doi.org/10.1080/107 $\underline{73525.2016 .1214795}$

41. Reed RM, Dransfield MT, Eberlein M, Miller M, Netzer G, Pavlovich M, et al. Gender Differences in First and Secondhand Smoke Exposure, Spirometric Lung Function and Cardiometabolic Health in the Old order Amish: A Novel Population Without Female Smoking. PLoS One. 2017;12(3):1-12. https://doi.org/10.1371/journal.pone.0174354

42. Bastian M. Internal Factors Related to Pulmonary Function Status of Workers at UD X. Indones J Occup Saf Heal. 2019;8(2):215-223. http://dx.doi. org/10.20473/ijosh.v8i2.2019.215-223

43. Skoczyńska A, Gruszczyński L, Wojakowska A, Ścieszka M, Turczyn B, Schmidt E. Association between the Type of Workplace and Lung Function in Copper Miners. Biomed Res Int. 2016;2016(5928572):1-15. https://doi. org/10.1155/2016/5928572

44. Pouryaghoub G, Nazem E. Effects of Simultaneous Exposure to Smoking and Welding Fume on Pulmonary Function Tests in Spot Welders. Tanaffos. 2021;20(1):64-70. https://www.ncbi.nlm. nih.gov/pmc/articles/PMC8355928/

45. Tagurum YO, Gwomson MD, Yakubu PM, Igbita JA, Chingle MP, Chirdan OO. Awareness of Occupational Hazards and Utilization of PPE amongst Welders in Jos Metropolis, Nigeria. Int $\mathrm{J}$ Res Med Sci. 2018;6(7):2227-2233. https://dx.doi. org/10.18203/2320-6012.ijrms20182808 
46. Husaini, Setyaningrum R, Saputra M. Factor Related with Occupational Disease on Welders. J MKMI. 2017;13(1):73-79. http://eprints.ulm. ac.id/5603/1/12.pdf

47. Hamzah NA, Mohd Tamrin SB, Ismail NH. Metal Dust Exposure and Lung Function Deterioration among Steel Workers: an Exposure-Response Relationship. Int $J$ Occup Environ Health. 2016;22(3):224-232. https://www.ncbi.nlm.nih.gov/ pmc/articles/PMC5102237/

48. Obarhoro OI, Chinyere RN, Blessed N, Ibe SNI, Iwuala CC, Ede AO, et al. Compliance in the Use of Personal Protective Equipment by Welders in Delta State, Nigeria. Int J Res Rev. 2020;7(1):21-26. https://www.ijrrjournal.com/IJRR Vol.7 Issue. 1 Jan2020/IJRR005.pdf

49. Dalimunthe KT, Mithami DB. Hubungan Pengetahuan, Sikap, dan Tindakan Terhadap Pemakaian Alat Pelindung Diri (APD) pada Pekerja Las Besi di Kecamatan Percut Sei Tuan Kabupaten Deli Serdang Tahun 2018. J Stikna. 2018;2(2):4754. $\quad$ https://www.jurnalstikna.com/index.php/js/ article/view/24

50. Aritonang NJ, Raha S, Salim A, Sinaga M. Analisa Faktor-Faktor yang Memengaruhi Perilaku Karyawan Kilang Papan dalam Penggunaan Alat Pelindung Diri di PT Hidup Baru Kota Binjai Tahun 2014. J IIm PANNMED. 2016;11(1):47-50. http://ojs. poltekkes-medan.ac.id/pannmed/article/view/70/61

51. Gaol YARL, Siahaan PBC. Determinan yang Berhubungan dengan Keluhan akibat Tidak Menggunakan APD pada Pekerja Bengkel Las Medan. J Heal Sci Physiother. 2020;2(1):61-67. https://doi.org/10.35893/jhsp.v2i1.35

52. Aprinita NK, Cahyo K, Indraswari R. Faktor - Faktor yang Berhubungan dengan Perilaku Penggunaan Alat Pelindung Diri (APD) pada Karyawan Pabrik Rokok Praoe Lajar di Semarang. J Kesehat Masy. 2017;5(5):1054-1062. https://ejournal3.undip.ac.id/ index.php/jkm/article/view/19235/0
53. Hariri A, Mohamad NN, Paiman NA, Ahmad ZAM, Zainal BSF. Heavy Metals Found in the Breathing Zone, Toenails and Lung Function of Welders Working in an Air-Conditioned Welding Workplace. Int J Occup Saf Ergon. 2018;24(4):646-651. http:// dx.doi.org/10.1080/10803548.2017.1368950

54. Imron MS. Gambaran Proteinuria pada Pekerja Bengkel Las di Pasar Cinde Kecamatan 24 Ilir Palembang Tahun 2017. Palembang: Politeknik Kesehatan Palembang; 2017. https://repository. poltekkespalembang.ac.id/items/show/483

55. Grahn K, Gustavsson P, Andersson T, Lindén A, Hemmingsson T, Selander J, et al. Occupational Exposure to Particles and Increased Risk of Developing Chronic Obstructive Pulmonary Disease (COPD): A population-based cohort study in Stockholm, Sweden. Environ Res. 2021;200(111739):1-9. https://doi.org/10.1016/j. envres.2021.111739

56. Rangkooy HA, Fouladi Dehaghi B, Ibrarahimi Ghavamabadi L, Marghzari L, Khodabakhshnejad F. An Investigation of Respiratory Symptoms and Spirometry Parameters of Welders in a Steel Industry. Jundishapur J Heal Sci. 2016;8(4):6-10. https://dx.doi.org/10.17795/jihs-37097

57. Mariani R, Pelucchi S, Paolini V, Belingheri M, di Gennaro F, Faverio P, et al. Prolonged Exposure to Welding Fumes as a Novel cause of Systemic Iron Overload. Liver Int. 2021;41(7):1600-1607. https:// dx.doi.org/10.1111\%2Fliv.14874

58. Li XL, Zhao X, Liu J, Ni Y, Guo XX, Liu T, et al. Research on the Short-Term Effects of Welding Fumes on Workers' Lung Function: a Panel Study. Chin Ind Hyg Occup Dis. 2021;39(6):469-471. http://doi.org/10.3760/cma.j.cn121094-20210329$\underline{00168}$

59. Retnawati H, Apino E, Kartianom, Djidu H, Anazifa RD. Pengantar Meta Analisis. Pengantar Analisis Meta. Yogyakarta: Parama Publishing; 2018. 